\title{
Prophecy and Doubt in Just Above My Head
}

\author{
Christopher Z. Hobson SUNY College at Old Westbury
}

\begin{abstract}
Written in the aftermath of the civil rights era's expansive hopes, James Baldwin's last novel, Just Above My Head (1979), examines a fundamental issue, the choice between hope and skepticism, or prophecy and doubt. Baldwin approaches this issue by questioning two cornerstone ideas of his fiction, the need for prophetic art and this art's focus on anticipating a renovated society, often pictured in terms adapted from apocalyptic biblical texts and Gospel music lyrics. Just Above My Head is Baldwin's fullest presentation of this kind of art and its linkage to apocalyptic hopes. He dramatizes these ideas in the art of his Gospel singer protagonist, particularly in a climactic scene of artistic dedication whose Gospel lyric envisions "tearing down the kingdom of this world." Yet Baldwin also unsparingly questions these same ideas through plot and the blues-inflected skeptical-tragic consciousness of his narrator. Responding to a 1970s moment when hopes for transcendent justice seemed passé, Just Above My Head's unique contribution is not to try to resolve the ideas it counterposes, but to face both the possible falseness of prophetic hope and our continuing need for it, and to present the necessity for choice in a final dream that holds the key to the novel's meaning. In presenting this issue through a sustained double-voiced narrative that reexamines its author's artistic practice and raises fundamental choices in outlook and conduct, Just Above My Head evidences the continuing artistic vitality of Baldwin's late fiction.
\end{abstract}

Keywords: Prophecy, prophetic art, apocalypse, apocalyptic, civil rights, Gospel, Daniel

Just Above My Head, James Baldwin's last novel (1979), responds to the eclipse of the civil rights era's utopian hopes by taking as its subject the competing claims of prophecy and doubt. Baldwin explores these claims by revisiting and 
questioning a double theme that has shaped much of his fiction: the need for prophetic art and the focus of this art on anticipating a transformed world that Baldwin consistently pictures in terms adapted from prophetic and apocalyptic Bible texts and Gospel music lyrics. Just Above My Head both celebrates these ideas, as manifested in the life and art of its protagonist, the Gospel singer Arthur Montana, and also questions them, through the narrative fact, known since the first pages, that Arthur has died at thirty-nine of unexplained natural causes, after a personal and professional decline that is never fully detailed. ${ }^{1}$ As his vehicle for this dual focus Baldwin creates a double-voiced narrative told by Arthur's more worldly and skeptical brother Hall, who expresses his own outlook alongside Arthur's, allowing both to speak in contention.

This contrast depends in part on a further one, between the novel's past time, the pre-civil rights and civil rights eras that occupy much of its length, and its post-civil rights era present, which shapes the novel though mentioned only fleetingly. In its past time narrative, Just Above My Head represents Baldwin's elegy for characters who, profane and human, yet "walked by faith." 2 The phrase echoes Paul's words on the apostolic life, "For we walk by faith, not by sight," and so evokes, through these characters, the epoch in African-American culture when its members lived at least in part by prophetic hope. ${ }^{3}$ Through the surviving characters' lives in the 1970s, in contrast, the novel pictures a time when, Robert Reid-Pharr suggests in a deeply-felt commentary, African-Americans have learned, or strive, "to forget the bloody injustices that have been done them and thus to re-member, to reproduce a world that, if not more just, is at least a bit more comfortable."4

Ultimately, Baldwin's narrator, even while recognizing something like ReidPharr's "forgetting" in his own life, does not accept such a stance as adequate to the past and present. Hall, a complex artist-narrator in his own right, instead adopts an implied aesthetic of tragic awareness. Yet, out of fidelity to those he portrays, he allows Arthur's contrasting (and perhaps abandoned) propheticapocalyptic consciousness to speak on its own and, further, to reenter the novel through its final dream sequence. The contrast between these opposed perspectives-rather than the validity of either-is, I argue, the novel's basic point. Through its overall structure and this narrative contrivance, Just Above My Head presents hope and skepticism as alternative life stances for readers' own decision: shall we, in our own present worlds, live according to the outlook of prophecy, or of doubt?

Beyond its particulars, this view of the novel suggests a revision of stillfrequent perceptions that it is artistically inept- "excessively rhetorical, structurally confusing, and lacking in coherent characterization," in one fairly recent view-and evidences Baldwin's waning fictional powers. ${ }^{5}$ If Baldwin mobilizes opposed character viewpoints and worldviews in a sustained double-voiced narration, reexamines his own basic aesthetic and social assumptions, and raises issues as fundamental as the continuation or abrogation of hopes for social 
reformation, the novel appears, instead, as a culminating work of substantial formal mastery and intellectual power.

\section{Baldwin and Prophetic Art}

Prophetic art works as a master trope for Baldwin, in that several major works speak of an art that, like biblical prophecy, wakes people to possible transformation in themselves and society. Biblical apocalypse, or the coming to earth of the heavenly city, similarly, functions as a trope projecting a future state of justice and freedom. For Baldwin, who as an adult held no formal religious belief, ${ }^{6}$ these ideas work as large-scale imaginative metaphors, though also suggesting human possibilities that in some undefined way are truly sacred. This argument, of course, goes against a significant though not hegemonic interpretive tradition that sees Baldwin as fundamentally, if sometimes ambivalently, hostile to Christian ideas. In the most sustained exposition of this view, Clarence Hardy assesses that Baldwin condemns a Christian God who is "white-that is, actively opposed to the flourishing of black life" - and "silent before black suffering," and that Baldwin does so "more strongly over time." As love for such a God must be self-defeating, Hardy believes Baldwin sees African-Americans' adoption of Christianity as rooted in "shame and not hope."7

The considerable evidentiary weakness of Hardy's analysis is that, except for Go Tell It on the Mountain, it does not deal in a sustained way with Baldwin's novels, particularly later ones. Some of his argument rings true. Characters like Rufus Scott in Another Country and Leo Proudhammer in Tell Me How Long the Train's Been Gone, for example, see God as "white" and rage at his unresponsiveness or cruelty to his presumed children. ${ }^{8}$ However, these elements of Hardy's analysis are not salient in other novels, and those after Train instead stress a long African-American struggle against human opposition. These novels, further, show family groups like the Riverses (If Beale Street Could Talk) and Montanas (Just Above My Head) as occasional churchgoers who are openminded and tolerant; the main religious opposition these texts present is not between God's unkept promises and human suffering, but between these characters' profane yet religiously observant lives and others' narrow-minded and hypocritical "sanctified" religion. The latter novel also shows church-affiliated characters who serve quietly and effectively amid the civil rights struggle's everyday perils. ${ }^{9}$ In important ways, then, Hardy's view that Baldwin increasingly repudiates an African-American Christianity based on "shame" misses a rapprochement with religious affiliation in Baldwin's later work, one other critics note. $^{10}$

More basically, an analysis that largely omits Baldwin's fiction also misses the way in which Baldwin, while rejecting Christianity as a belief system, adapts and revises core Christian conceptions-especially of prophetic office and the apocalyptic end of tyranny-as an expressive language for conveying human potentialities. Studying Baldwin's quasi-metaphoric uses of these ideas helps us 
understand his treatment of art and society in several works and helps make clear why Just Above My Head uses a Gospel singer to embody transcendent social hopes. Doing so also lets us discern, alongside specific topics such as the civil rights movement, homophobia, and the contradictory qualities of Black churches, the text's overall concern with whether a general transformation of society is possible. Finally, so far as Baldwin himself has been a prophetic singer, understanding his biblically inflected language helps clarify his reckoning with his own art and the possibility that it has been mistaken.

Prophetic and apocalyptic texts are not, of course, univocally liberatory. Recent studies have identified imposition of cult orthodoxy and a sometimes murderous misogyny, for example, as threads in the prophetic literature. ${ }^{11}$ This said, most studies of these variegated texts see an emphasis on justice and righteousness (understood as fair treatment and substantive beneficence, especially toward the community's weak and poor) as similarly salient, as, also, most scholars of biblical apocalypticism find in it a call for ultimate justice for the suffererscrucial elements in African-American understandings. ${ }^{12}$ Further, these views in African-American preaching and reading traditions-like other convictions reaching back to Richard Allen and beyond, such as of God's opposition to oppression-should be seen not as naïve misreadings but as considered emphases, acts of theological interpretation..$^{13}$ Baldwin practices a similar, nontheist "theological interpretation" in selecting and sometimes revising or adding to biblical patterns and references to suggest human impulses toward liberation.

The conjoined ideas of prophetic art and its designation of a future new freedom enter Baldwin's work as early as "Sonny's Blues" (published 1957), whose final scene shows an arguably redemptive art creating a momentary state in which "[f]reedom lurked around us." ${ }^{\text {"14 }}$ Each of the three novels that follow also reflects in some way on the truth-telling or reformative ends of art and evokes some expected future social reform or upheaval. ${ }^{15}$ Following on these works, Just Above My Head presents Baldwin's most extended portrayal of prophetic commitment in art and its linkage to an expected apocalyptic end to injustice. These emphases, not widely discussed in commentaries, provide the basis for a climactic scene of dedication, focused on a Gospel song of the fall of empire that also serves as one of the novel's epigraphs. ${ }^{16}$

Baldwin leads us to this scene through an account of Arthur Montana's early career, from before the Korean War to the early and middle civil rights years. The lyrics Arthur sings over this period, as an adolescent in the short-lived Trumpets of Zion quartet and solo after its breakup, develop from a general Gospel embodying prophetic hopes ("Savior, Don't Pass Me By,") to an eschatological hymn ("The Comforter"), sung amid the terror of the civil rights movement, when Arthur's friend, former Trumpets of Zion partner, and present accompanist, Peanut, is kidnapped and presumed killed after a church rally near Atlanta. ${ }^{17}$ Hall's commentaries further suggest Gospel art's roots in communal experience and the artist's function of giving form to impulses originating beyond herself or himself: "[A] mighty work," Hall asserts early 
on, "was being worked, in time, through the vessel of my brother, who, then, ... belong[ed] to me no longer." 18 The words evoke the biblical tradition that prophets are chosen to speak God's judgments, acting, in effect, as his vessels and transcending their specific identities. ${ }^{19}$ Yet Baldwin reworks and expands the tradition: if inspiration comes from beyond the singer, equally the singer cannot receive it unless true to her or his inmost self. "When you sing," Arthur tells Hall in their first real discussion of his homosexuality, "[y]ou've got to be the song you sing. You've got to make a confession." 20 So, in Baldwin's revision of biblical prophetic commissioning, the singer must open her or himself to those she or he sings to, emotionally if not explicitly, in order to sing truly.

Baldwin does not fully specify the source of the artist-prophet's vision. By inference, as just seen, it is partly the artist's inmost soul. In part, the source is the prophet's own time and history and the life of those around her or him, as expressed in a late meditation by Jimmy Miller, Arthur's collaborator and surviving lover:

The song does not belong to the singer. The singer is found by the song. Ain't no singer, anywhere, ever made up a song-that is not possible. He hears something. I really believe, baby, at the bottom of my balls, that something hears him, something says, come here! and jumps on him just exactly like you jump on a piano or a sax or a violin or a drum.... That sound you hear ... is the sound of millions and millions and, who knows, now, listening, where life is, where is death ${ }^{21}$

That great artists voice common dreams and hopes is a commonplace; the core of Jimmy's statement is that this action, for true artists, is in no way voluntary. "[S] omething," Jimmy says, "jumps on" the artist, uses the singer as a saxophonist uses that instrument: with regard only for its technical limitations, and then only to push and pummel them. This "something," not further defined, is essentially a mystery-it is the link between the experience of millions and the artistic process that lets the artist's sound become theirs. In Baldwin's use, something like Shelley's "spirit of the age" reaches the prophet-artist through African-American experience crossing generations and extending out into the community's current life. ${ }^{22}$

With these ideas and Arthur's musical evolution as backdrop, Baldwin moves to a depiction of commissioning for and dedication to a directly apocalyptic art, when Arthur is called on to sing in a Paris jazz club. ${ }^{23}$ Though set soon after the events mentioned above, this scene is not shown as a specific response to them. Rather, it appears as an artistic maturation, a generic shift in AfricanAmerican music, and a release of what is already within and around Arthur. Baldwin conveys all this by bringing Arthur, with his French lover Guy, to the nightclub, where he encounters an aging blues artist, Sonny Carr. The mixedrace trio of U.S. musicians and the audience of French, European, Black and white American, black African, and north African aficionados embody the 
world's turmoil and, in their precarious unity, its hope. The older singer's acquaintance long ago, as an already-mature artist, with Arthur's then-young pianist father Paul suggests a passing of performing authority between artistic generations. The shift is generic, too, as Carr performs a set of blues, folk, and convict work song standards- "Water Boy," "Jack of Diamonds," "See See Rider," "Take This Hammer," and "Yellow Dog Blues"-before bringing Arthur on stage and bidding him, "Sing 'Daniel!!"24

This call signifies a transition in the art needed to articulate the community's needs. The shift is simultaneously from blues and songs of labor to Gospel, and from enduring suffering to its apocalyptic end as the aim African-American art points to. Finally, Arthur's response signifies the artist's function as "vessel" (above): he reaches beyond performing intention into his memory, into the song's past transmission, and into the world around him calling for such a song. For, before Carr speaks, Arthur has been briefly unable to think of any song at all, but at Carr's directive, "[s]till not certain of the words, Arthur opens his mouth, and the words come out!"25

\author{
Daniel \\ saw the stone \\ that was hewed \\ out the mountain,... \\ Daniel \\ saw the stone \\ that was rolled \\ into Babylon... \\ Jesus is the stone \\ that was hewed out the mountain, \\ tearing down \\ the kingdom of this world! ${ }^{26}$
}

The song, "Daniel Saw the Stone," is a cornerstone of apocalyptic Gospel singing, originating in some versions before 1907 and in Baldwin's before 1926. It derives from a core text in general apocalyptic thought, Daniel's interpretation of Nebuchadnezzar's dream of a stone that smashes an idol of gold, silver, brass, iron, and clay-representing successive, degenerating kingdoms-and becomes a mountain filling the earth:

And in the days of these kings shall the God of heaven set up a kingdom, which ... shall break in pieces and consume all these kingdoms, and it shall stand for ever.

Forasmuch as thou sawest that the stone was cut out of the mountain without hands, and that it brake in pieces the iron, the brass, the clay, the silver, and the gold; the great God hath made known to the king what shall come to pass hereafter: and the dream is certain, and the interpretation thereof sure. ${ }^{27}$ 
The stone "cut out of the mountain without hands," signifying the spiritual force that overcomes tyranny and oppression, became the topic of an 1884 sermon by the famed Richmond Baptist minister John Jasper. ${ }^{28}$ Baldwin's The Fire Next Time (1963) and Martin Luther King's "Dream" speech both allude to the phrase-for Baldwin, the generations of African-Americans who have withstood persecution "were hewing out of the mountain of white supremacy the stone of their individuality;" King tells his hearers, "With this faith, we will be able to hew out of the mountain of despair a stone of hope." ${ }^{29}$ Among modern theological commentators, John J. Collins notes that the statue's destruction denotes "the transcendent power of God to destroy all idols and the kingdoms that worship them;" Gerhard von Rad, with a more temporal emphasis, observes: "The main point is, of course, perfectly clear: with the terrible fourth kingdom [of iron and clay] into which the empire divides, world history has come to an end. The stone which is to be cut 'by no human hand' ... is an image of the kingdom of God that fills the whole earth." 30 The song, whose thematic importance Baldwin underscores by also using it as an epigraph to Book One, promises the end of all tyrannic empires-then Babylon and Persia, today those of our world. ${ }^{31}$ The corollary, the advent of God's kingdom, is unspoken but plain to those who know Daniel.

Once Arthur sings solo, Carr and he, elder and youth, sing two songs together- "The End of My Journey" and "Another Building Not Made with Hands." These tell of the long work of witnessing for truth and of God's acceptance of this work. The first looks to the day "when I come / to the end of my journey, /. . weary of life, / and the battle is won;" the second gives God's assessment and then the singer's: "I'm pleased with what you've done, I and your race has been run" and, echoing Second Corinthians and varying Daniel: "I praise God, I have another building, / not made with hands!" 32

This certainty that prophetic work is well done is necessarily acquired by faith or personal belief, whether in God or some vision of the future. The verses that the last song alludes to speak of this issue. Paul says that we long for "our house which is from heaven," before concluding, in the words Baldwin has used of the Trumpets of Zion, "[W]e walk by faith, not by sight." 33 This capacity Sonny wills for Arthur; yet Arthur will not be able to sustain it, and so the biblical allusion serves partly to foreshadow what lies ahead.

\section{Questioning Apocalypse}

The Paris scene marks a plateau in the protagonist's life. Further, its placement at the close of Book Four-Just Above My Head's longest unit, covering the hopes and losses of the civil rights years-seems to make it thematically summative. Yet, as the present-time setting in the mid-1970s indirectly makes clear, the novel's central fact is the postponement of the apocalyptic overturn of "Babylon" that Arthur's song promised. The book, then, questions its own apparent cornerstone beliefs. 
In real history, the sixteen or so years covered by the novel's closing section saw, first, the climax of radical and revolutionary agitation in the late 1960s (omitted in Baldwin's text) and, then, the dying down of mass civil rights and radical agitation in the United States between about 1970 and 1973, along with the ebb of the period's international radical cultures. ${ }^{34}$ In the book's only direct reference to this shift, chronologically displaced to the middle of the southern tour during which Peanut will be killed, Hall implies that the change brought a massive collapse of hope and commitment:

[W] hen the dream was slaughtered, and all that love and labor seemed to have gone for nothing, we scattered ... each into his or her own silence. It was in the astounded eyes of the children that we realized, had to face, how immensely we had been feared, despised, and betrayed. Each had, with speed, to put himself together as best he could, and begin again. ${ }^{35}$

Hall's meaning, allowing for overstatement, is clear. He refers first of all to the assassinations of the 1960s_of King, evoked by the single word "dream," of Medgar Evers and Malcolm X of Baldwin's acquaintance, and many more. Further, in saying that "all that love and labor seemed to have gone for nothing," Hall points to the "dream," beyond legal changes, of what the Student Nonviolent Coordinating Committee's 1960 founding statement called "a social order of justice permeated by love," as well as to the even more sweeping hopes of that time for a freeing of "Babylon's" captives. ${ }^{36}$

In the novel's present, "Babylon's" temporal power appears unshaken. Hall and Julia-his ex-lover and Jimmy's sister-now live in semi-suburban Bronx and Yonkers neighborhoods; Hall's children seem accepted at school. But during Hall's drive to Julia's house a car ahead flaunts, "AMERICA: LOVE IT OR LEAVE IT;" and Arthur, visiting Hall sometime in these years, wonders "what goes on behind all these careful shutters. It can't be-nothing. But ... it sure don't seem to be something." 37 The neighborhood, Arthur says, "sucks. With a straw. You ever look into the faces of these people? Oh, baby. Shit. How did that happen?"38 Hall for his part jokes, "We couldn't all make it to Canada. Some of us had to stop here." 39 Hall's implication, surely, is that "here" is not a free country and that if life is better than in the past, there is no real prospect of ongoing change; Arthur, in turn, appears to despise the reality Hall has uneasily compromised with, yet also to see no way out of it. These characters, then, live African-American middle class lives in the wake of the civil rights movement: not free though freer, half-integrated into a sterile American prosperity, against which Julia's African-accented clothes and true African décor seem an inoculation. ${ }^{40}$ Underlining "Babylon's" power is the path of desolation leading to the present: of the original Trumpets of Zion members, Peanut and now Arthur are dead, Crunch-Arthur's first lover-is insane, and Red is an addict and ex-con on methadone; ${ }^{41}$ Peanut's grandmother and others are dead 
as well or, like Red's mother and Hall and Arthur's mother Florence, have exiled themselves from the city that brought down their sons. ${ }^{42}$

This present-time situation frames the novel's narrative and its clash of ideas. Narratively, the major issue in the novel's last section is the causes and dimensions of Arthur's decline. Lynn Orilla Scott, one of the work's best interpreters, attributes this deterioration to Arthur's "corrosive, internalized homophobia," which she sees as responsible for his personal and family problems and his loss of creative direction. ${ }^{43}$ Clearly sexual self-doubt is operative on some levelHall has referred earlier to a future time when Arthur would sink "beneath the double weight of the judgment without and the judgment within." ${ }^{4}$ Yet Scott's analysis does not take into account either the impact of the social quiescence just sketched or the independent influence of Arthur's musical choices, discussed below. Both must be involved in the downward course of an artist dedicated, at the high moment of his faith (above), to heralding the fall of "Babylon."

On the deeper level of contested ideas, the present-time framework affects Just Above My Head through a disjunction between Arthur's initial prophetic consciousness (possibly compromised in later life) and Hall's own assessment of the novel's events. Differences between the brothers' outlooks begin with Hall's religious skepticism, expressed in his comments that " $\mathrm{t}]$ he energy called divine is really human need, translated" and that God is something "we have created." ${ }^{45}$ Hall deals respectfully with Arthur's religious belief-he can imagine, for Arthur, that he and Jimmy confess their love "in the hearing of men, and in the sight of God." 46 But his disbelief establishes distance between their base attitudes. Hall, further, shows unstated skepticism toward the assumptions underlying Arthur's prophetic vocation. Hall is a political radical who hates the Korean War before he goes to it, who sums up afterward, "It was bitter to see that you were part of a country that didn't give a fuck about you, or anybody else," and who in the present, decades after the Supreme Court's 1955 "All deliberate speed" order, interprets it as designating "the time needed to outwit, contain-and demoralize-the niggers." 47 And he loves his brother desperately and will do anything, go anywhere, to help him in his mission. But, as his "We couldn't all make it to Canada" (above) tacitly concedes, Hall shows little confidence that injustice is transient, as a prophetic outlook must assume. Hall does not devalue earlier decades' emancipatory and apocalyptic moods, but has not found his own key to hope.

More broadly still, while honoring Arthur's effort, Hall places his and others' lives under the lens of a human experience that never changes: "Yesterday, we were the children, Ruth and I and Julia: we're the old folks now, and this is what will happen to Tony and Odessa, please God be willing;" "I have wondered, more than once, why I started it [the book we are reading], but-I know why... It is an attempt to face both love and death." ${ }^{28}$ This recognition of time, loss, and continuity from generation to generation, true and moving, also implies the emptiness of apocalyptic claims: life goes on, is lost and renewed, in times past, now, and times to come. What we hope for our lives is that they 
pass to completion with some joy and without too much pain, and we hope the same for our children and theirs-with some gains in status or comfort over the generations. For ordinary people, indeed-though perhaps they hope for heaven-questions of redemptive justice, a new world, seldom arise or seem real, except, significantly, when the whole society stirs, as in the 1960s. And so, through a worldview conveyed by implication rather than outright statement, Hall as narrator calls into question the transformative expectations he has made central in Arthur's story.

\section{Questioning Prophetic Art}

Along with the possibility of redemptive justice, Just Above My Head questions the power and efficacy of prophetic art. Baldwin raises this issue through the plot choice of having Arthur, in his later career, develop as a "crossover" artist who moves from Gospel and Gospel-inflected song to classic and contemporary jazz and pop as his core repertory. Not at once but in the course of years, his musical direction takes him further and further not just from Gospel but also from the prophetic art he developed in his early career. The text's scant but definite evidence is that the cost of Arthur's change is a sapping of his belief in his worth as an artist, as a community voice, and, ultimately, as the herald of a new world he once felt himself to be-a "Trumpet of Zion."

The scattered signposts to Arthur's road are fairly clear when tracked. We learn early that at some point Arthur "branched out from gospel" and that, in consequence, "people in the church ... turned against him" with "spiteful" language that "lacerated" him. ${ }^{49}$ Later, Hall mentions that around the time of his Paris trip Arthur was "being pressured to 'branch out' from Gospel," and "was warily considering this." 50 Finally, much later in the chronology, when Arthur has been with Jimmy for some years, the two discuss the issue after a day's rehearsing, and tentatively try a 1945 jazz-pop standard, Buddy Johnson's "Since I Fell for You." 51 Arthur's turn toward a new style is clear, especially since the song he and Jimmy were rehearsing, Johnson Oatman Jr.'s "Lift Him Up" (1903), is a strongly-felt evocation of redemptive sacrifice with a social outreach message posing Jesus' example as the way to "reach the masses, men of every birth." 52

Baldwin's account draws in part on the careers of such originally church-based singers as Rosetta Tharpe, Sam Cooke, the now less-known Donny Hathaway, Marvin Gaye, and Aretha Franklin, each of whom "crossed over" from Gospel and church singing to club and concert performance, often meeting the blowback from Gospel audiences that Hall mentions for Arthur. Some, particularly Gaye, were deeply conflicted over their strong sexual drives, another possible similarity with Baldwin's story. ${ }^{53}$ Yet it is also true that some of these artists, Cooke and Gaye specifically, moved toward rather than away from a socially conscious art in their new careers-in the same period, the mid-1960s to early 1970s, implied as that of Arthur's decline. ${ }^{54}$ Baldwin, in contrast, assigns Arthur lyrics of personal 
love and loss-from "Since I Fell for You," the final lines, "I guess I'll never see the light / I get the blues most every night, / Since I fell for you," and, from Arthur's last performance, of "Feelin' Alright” (1968), by Dave Mason, "Boy, / you sure took / me / for one big ride" and "Lord knows, / I've got to stop believing / in all your lies." ${ }^{\prime 5}$ Arthur, then, has not adulterated his art by "branching out" as such, butin contrast to at least some real crossover artists of his period-is a once prophetic artist who has turned from this component of his art.

By his last months, not only is Arthur's career fading, but he has grown quarrelsome, is deeply into drink and drugs, and has fallen in with "creepy people." ${ }^{56}$ Jimmy feels, two years later, in present time, that "[i]t wasn't him singing, anymore... That's what he felt, I know. You [Hall] do, too. But he couldn't go back, either." 57 While Jimmy's first comment takes in Arthur's whole situation, "he couldn't go back" most probably means he could not reverse his musical evolution. In turn, a loss of belief in his musical integrity may lie behind Arthur's catastrophic last performance, when, "certain that Jimmy was ashamed of him, and that he should have been ashamed of him," and "drunk, stoned" besides, Arthur suffers a near-total breakdown of artistic control, singing "Feelin' Alright," which he has always handled "as a funky, light, blues-ballad," as personal lament, losing control of the style and tone and, almost, the beat, and barely finishing. ${ }^{58}$ Sometime in these final months, apparently, comes the moment Hall tells earlier as foreshadowing, "when Arthur would cry out, weeping briny tears, Look! what they done to my song?" 59 "They" may refer to the agents or producers who initially "pressured" Arthur to move beyond Gospel-that is, to commercial control of art and self-commercialization by the artist-or to the "creepy" people Arthur has been seeing. ${ }^{60}$ But it must also refer partly to Arthur himself, what he has done to his song-in the last analysis, he has chosen his artistic course. So his tears are not just for his behavior and loss of artistic discipline, but for the loss of the musician he began as.

Some such sense would seem to lie behind Jimmy's assessment of Arthur's predicament in his final monologue, which makes three important statements about music and the music world. First, reflecting on his and Arthur's homosexuality and whether homosexuality is "psychological," Jimmy asks, "If that was true, how could we sing, how could we know that ... we are the song we sing?" 61 Then, after a pause, Jimmy moves to the points noted earlier on the artist's "song"- that "[t]he singer is found by the song," whose sound "is the sound of millions and millions." "62 Last, he sums up:

Arthur got hurt, trapped, lost, somewhere in there. I had to deal with some of his old friends, lovers, leeches, from Paris to London to Amsterdam, to Copenhagen: all Arthur wanted was for the people who had made the music, from God knows who, to Satchmo, Mr. Jelly-Lord, Bessie, Mahalia, Miles, Ray, Trane, his daddy, and you, too, mother-fucker, you! It was only when he got scared about what they might think of what he'd done to their song-our song-that he really started to be uptight about our love. ${ }^{63}$ 
In these linked comments Jimmy is in part saying what Arthur has said already: the singer must "make a confession" emotionally if not explicitly (discussed above). ${ }^{64}$ So, shame over homosexuality, a running idea in Jimmy's monologue, can stanch the source of the song. However, this is unlikely to be the sole cause of Arthur's shame, if only because some of those Jimmy mentions, such as Bessie Smith and Mahalia Jackson, were themselves thought or known to be homosexual or bisexual. ${ }^{65}$ Equally, turning from the springs of one's most intense musical expression-for Arthur, its redemptive purpose-can itself bring shame, which can, as well, shatter the ability to lay oneself open in music. We can now see Arthur's evolution as mixed, a combination of shame at abandoning his deepest inspiration and of resurgent sexual self-doubt that both feeds and stems from artistic impasse. We can also understand that Jimmy's words about the song, though not directly meant as criticism, state an ideal in music that Arthur has lost touch with. Finally, we can assess Jimmy's list of those Arthur feared to shame. It begins with "God knows who," the griot or slave singer who created the song, and includes the lineage of those, from Armstrong to Coltrane, who were not necessarily all prophetic artists but created a communal sound, one that refracted, with artistic independence and depth, the community's past and the open possibilities of its future. This community tradition, roughly, is what Jimmy means by "our song," and Arthur's prophetic art has been one expression of it, which Arthur has failed to carry through.

This sketched artistic history implies a critique of prophetic art-rather than just of Arthur's turn from it-because of the purposes with which Arthur is shown to have developed his art and the circumstances in which he tried to follow its requirements. The purposes become clear in two short passages placed before and just after Arthur's then-lover Crunch is drafted and sent to Korea:

My brother, turning sixteen then, was alone, and in torment, and in love. He sang, he had to sing, as though music could really accomplish the miracle of making the walls come tumbling down.... But the song which transformed others failed to transform him. ${ }^{66}$

He was singing for Crunch-to keep Crunch safe, and to bring Crunch back, and he was singing for me, to keep me safe and to bring me back: he was singing to hold up the world. There entered his voice then, therefore, a mightily moving, lonely sweetness and the people were transfigured and transfixed: he sang to their love and their worry; he sang to their hope. With his song, and standing before the people, he made his confession at the throne of mercy, and knew himself, then, as his voice issued from him, to be redeemed, in the hands of a power greater than any on the earth. His love was his confession, his testimony was his song. ${ }^{67}$

The latter passage shows one of the few moments of full unity in Arthur's life. His confession to an unspecified higher power is of love, love of Crunch (and so sexual love) and of Hall, and connects him to those whose love he sings to, 
whose brothers, lovers, sisters, parents, children are in Korea, on the street, or simply making their way through life. And Arthur, who must know that his song alone cannot bring anyone home, much less "hold up the world," presumably does believe that all whom he sings to can, and perhaps that God can, and that his voice joins him to them. Indeed, the first description asserts, he sings with a conviction tantamount to believing (Hall skeptically inserts "as though") that his song can act as Israel's trumpets did at Jericho.

There are two warnings in these descriptions, one direct and one implied. The first is Hall's assessment, "But the song which transformed others failed to transform him," referring most directly to Arthur's pain over Crunch's affair with Julia but also to his later disorientation and shame. ${ }^{68}$ However complex the anguish Hall speaks of, at bottom he is identifying a variant of the general problem of prophesying what will not occur in one's own time. The prophet speaks of renewal, but lives in the unrenewed time, which tests whether she or he can long "walk by faith." 69 Baldwin arranges events so that by the time of the Paris performance, Arthur's faith has already been severely tested. Peanut is dead, his grandmother dead, Red a junkie, Red's mother gone; only Crunch's full catastrophe lies ahead. Yet Arthur's response in Paris, we know, is to deepen and extend his belief and commitment. Ultimately, however, these decisions lead back to the same test, in modified form, when the oppositional energies that in Paris may have seemed limitless dissipate. In the social landscape of Baldwin's 1970swhen Arthur looks out Hall's window "as still and as astonished as a prisoner" the idea of a transformed world can seem not just abstract, but passé. ${ }^{70}$ The test of faith posed then for a musician of prophetic hope has a simple form: why not try something new?

The hidden issue in Hall's description, "the song which transformed others failed to transform him," lies in the assumption behind its first half, and is also presented by the movement's rise and ebb. Prophetic art has been based on the idea that art can transmit a spark to its hearers that touches something essential-a need or possibility of standing forth, as the earth's despised, to effectuate a new beauty and honor. The waning of oppositional movements suggests that these possibilities may not be fundamental, or may stand alongside others just as fundamental; people may on some level long for transformation, yet also-in other moods, or after exhausting efforts-yearn for some advantage in a hard world and hope to get on with their lives. If so, prophetic art would touch, not their very core, but one emotion among many, would be ancillary and not essential, a component or even accidental aspect of a striving among the people that surges and recedes for its own reasons. So, Arthur's music would not be, as Hall says, "transfigur[ing]," but would only confirm and focus what listeners already feel. Unlike the issue of prophetic steadfastness, this possibility challenges the rationale for and efficacy of prophetic art in toto.

Hall, then, questions both the possibility of a new world and the idea of an art that awakens its hearers to this possibility. Yet, simultaneously, his picture of Arthur's disintegration shows the deep cost-in self-conception and artistic 
direction-of abandoning such an art. Further, the structure of Hall's narrative allows Arthur's original dedication to remain in the novel, and even emphasizes it, permitting that dedication to be judged against Hall's reappraisal. In both ways, Hall's narrative design asks readers to balance nonprophetic against prophetic ways of viewing the world.

\section{Rain and Fire}

At the close of the novel's action, three ideas seem possible about how to live and make art in a restabilized society. One is to embrace the very limited changes achieved by the novel's present time while accepting that society remains unjust and can be changed only incrementally. In the commentary mentioned earlier, Robert Reid-Pharr argues that this is, in essence, the novel's meaning. Reid-Pharr believes Just Above My Head is ultimately "hopeful" because Hall "lives to tell a beautiful story to his two beautiful children" and, more fundamentally, because of the surviving characters' ability "to forget the bloody injustices done them" and fashion for themselves a world that, "if not more just, is at least a bit more comfortable" (above). Reid-Pharr relates this ability to what he presents as basic qualities of American and African-American life. The very shallowness of Americans' historical awareness, he argues, creates "the incredible luxury of forgetting and thus of choosing a course different from the bloody past." More specifically, Reid-Pharr pinpoints a capacity for disengaging and moving on as basic to the race's life, noting that "generations of Black Americans, faced continually with communal exploitation and personal insult," have "told one another to "forget it." 71 Reid-Pharr seems, then, to link the ability to "forget" to abandonment of the utopia of a "just" world in favor of a "more comfortable" one. Though he does not discuss what this might mean for art, surely it would imply the art of feeling and irony that Arthur tried to practice.

Reid-Pharr's view does describe something like Hall's present stance as a character-seen in his thankfulness for having come this far, the muted hopes of his middle age, and his overall view of life. Yet as an artist Hall excludes this perspective. Rather than "forgetting," his account relentlessly insists on injustice past and present (Peanut, Crunch, Red) and on the need for memory. The novel's exploration of the past, after all, begins with two questions from Hall's children: Tony's "What was my uncle-Arthur-like?" and Odessa's "Who's Red?"72 It is Hall who supplies the novel's history of "bloody injustices," and he does so in compulsion as an artist to transmit memory to "the children."73 Hall's consciousness, then, is more nearly tragic than Reid-Pharr implies. Something like a tragically-inflected blues attitude, in sum, is possible as a second response to the novel's present reality. Yet this attitude comes with an unavoidable corollary. A parent's early death, one's own aging, even a brother's selfdriven death-offset by one's survival and one's children's burgeoning livescan belong to a narrative of mixed joy and sorrow, essentially unchanging over time. The murder of a civil rights worker and the death in grief of his 
grandmother can belong to this same narrative only if one affirms-as indeed many would-that exclusionary and brutal structures of power are permanent parts of human life, changing in who oppresses whom but never in essence. Whether this is so is the unspoken question behind Baldwin's apocalypticism, and the question posed by the collapse of apocalyptic hope in Just Above My Head.

A third response to the novel's present period, of course, would be to continue asserting prophetic art's value and the possibility of overall reformation at some future time. Arthur is the character most associated with the prophetic outlook, but we know little of his ideas in the novel's recent past. In the scene in which he mocks Hall's neighborhood (above), we infer that Arthur shuns Hall's accommodation to current reality, while himself having no clear alternative. But this knowledge tells us nothing of how Arthur, at that time, would regard prophecy and apocalypse-as valid ways to understand the world, no longer valid, or never valid.

Rather than resolving the tension among these viewpoints, Baldwin allows the major views he has held in balance to speak in a final dream scene that is simultaneously a portrayal of Hall's continuing sorrow and a prophetic vision he cannot fully interpret. ${ }^{74}$ Dreams and dream-visions are a prophetic genre important in some biblical contexts, particularly in Daniel: both Daniel 2, discussed earlier, and a related account of the four successive kingdoms as beasts from the sea in Daniel 7 are dream interpretations. Hall's dream, however, represents not an angelic revelation but what his unconscious mind is aware of that his conscious thought cannot fully understand, and offers, in place of an authoritative interpretation, two song texts and a final comment.

The dream shows characters from Hall's past-his father Paul, now dead, his mother Florence, and others-struggling up a road through rain, toward Hall, Julia, Jimmy, Arthur (restored by Hall's wish), and the children, who are sheltered on a country porch. The characters on the road are all associated with a long-ago Christmas, probably in 1950, that marked a high point of the family's love; gifts from that Christmas figure in the dream. ${ }^{75}$ So the dream condenses the novel's decades-long time span, and the difference between eras that this span incorporates, into one vision. Simultaneously, it poses the novel's main issue in veiled form, as Arthur twice asks Hall, "Shall we tell them? What's up the road?"76 The question "torments me [Hall], like a song I once heard Arthur sing, and can't now, in my dream, for the life of me, remember"-and the dream moves to the songs and its conclusion, when Hall replies, "No, they'll find out what's up the road, ain't nothing up the road but us, man," and wakes, his pillow "wet with tears."

Arthur's question is in essence about the need for prophecy: shall we "tell them" what will come, in our time, and, so far as we can, in time to come? The two songs represent possible answers. The rain-dream-manifestation of the tears that must already be wetting Hall's cheeks-evokes the first, "Hurry Down Sunshine," by Mary Fix and Will Shade (1927). The song lyric, "Hurry down, / 
sunshine, / see what tomorrow brings... / The sun went down, / Tomorrow brought us / rain" embodies the universal experience of hope and disillusionment, the pervasiveness of sorrow and "trouble" in life: "Hurry down, sunshine," we say, anticipating tomorrow, only to find that "tomorrow brought us rain." ${ }^{78}$ The song's genre, of course, is blues, Baldwin's music of pain, sorrow, and laughter. $^{79}$

This song, however, is not one Hall has heard Arthur sing; Hall cannot process Arthur's repeated question until he hears the song Arthur sang, or one like it, and now he remembers "the beginning of a song I used to love to hear Arthur sing," evoked by Hall's consciousness of his pillow as the first was by his tears. ${ }^{80}$ The verse is part of "When the World's on Fire," a Gospel classic: "Oh, my loving brother, when the world's on fire, Don't you want God's bosom to be your pillow?"81 These lyrics directly communicate an apocalyptic beliefthe world is on fire-and so the song represents, for Hall's dreaming mind, Arthur's alternative to his own skepticism. In his sleep, Hall is able to read Arthur's song in his own way, as embodying a hope he cannot share, and his answer frees him to wake and acknowledge his tears. Hall's reply to Arthur is his answer to the book's central issue: prophecy is useless and redundant, for what is to come is much like what has passed; we are what is "up the road," and our children's lives after ours, not any transformed world. The questioning of all elements of Baldwin's belief system that has marked this novel, then, comes together in Hall's words.

Arthur's song, however, requires a prophetic interpretation to balance Hall's, one unstated in the text but implied by biblical and Gospel contexts. The song derives from the main New Testament source for the idea of the world's end in fire, the Second Epistle General of Peter, which states that the heavens and earth are "reserved unto fire against the day of judgment," when "the elements shall melt with fervent heat, the earth also and the works that are therein shall be burnt up." 82 According to Daniel J. Harrington's commentary, "[T]his theme is not found elsewhere in the NT [New Testament]." ${ }^{\prime 3}$ The song, then, derives from this passage. It is, in fact, generally associated with it. "The World on Fire," a sermon on these verses by W. A. Criswell, longtime pastor of First Baptist Church, Dallas, after urging that apocalypse is a cleansing fire to be hoped for, and not physical destruction, moves to its conclusion by mentioning a group of seminarians singing these lyrics, and inviting the congregation, "Did you ever hear that? Could you sing it with me? Let's try." 84

The discussion in Second Peter involves Just Above My Head's core opposition, between prophecy and doubt. Composed not by the apostle to whom it is attributed but most likely by a late first-century writer, Second Peter is concerned with the delay in the "parousia," or triumphant return of Christ, which Jesus's followers had generally expected to occur before the dying-out of the apostolic generation. ${ }^{85}$ The letter is cast as a response to "false teachers" or "scoffers" who rejected the promise of apocalyptic transformation in part by claiming that "since the fathers fell asleep, all things continue as they were from 
the beginning of the creation"-broadly, what Hall assumes about the persistence of joy and pain through time. ${ }^{86}$ This claim Second Peter contests in a two-part argument: the "scoffers" assumption is false and so, therefore, is their conclusion.

[By God's word] the world that then was, being overflowed with water, perished.

But the heavens and the earth, which are now, by the same word are kept in store, reserved unto fire against the day of judgment[.] ${ }^{87}$

The writer argues that the world has not been unchanged since "the beginning of the creation" but has undergone fundamental change before-in the Floodand will do so again. So the verses are relevant to the idea of a renewed world that has guided much of Baldwin's work, and to Hall's challenge to that idea. Additionally, the passage is notable as the origin of the "prophecy, re-created from the Bible in song by a slave," that became the title of Baldwin's most famed work. ${ }^{88}$ That prophecy is inextricably associated with Second Peter, whose words have "found a firm place in Christian consciousness ('the fire next time')," as Harrington notes. ${ }^{89}$ Arthur's song is, then, reminding the knowing reader of Baldwin's past use of apocalyptic reference as it makes its own point that the world is on fire and that it is right and true to expect its transformation and to keep faith when faith seems no longer justified. Through this tacit selfreference, of course, Baldwin implies that not just Arthur's but his own artistic perspectives may have been mistaken. And yet this possibility is not his fundamental point.

By the novel's end, Baldwin has, though indirectly, made the cause of Arthur's decline at least partly clear: a catastrophic loss of inner confidence and direction, related to the incompatibility of his prior prophetic-apocalyptic outlook with the temper of the new time, and involving abandonment of his prophetic stance in art, loss of a clear redemptive hope, and renewed sexual self-doubt. By contrast, Baldwin leaves unresolved the contention between outlooks that Arthur's history, the novel's juxtaposition of eras, and Hall's commentaries all imply. Indeed, he reintroduces the prophetic-apocalyptic view inherent in the story as an alternative to Hall's, through Hall's sleeping memory of Arthur's time of faith.

In this presentation of opposed perspectives in tension, Baldwin speaks in and from a 1970s moment in which the possibility of transformation seems to have gone out of the world's life. His unique contribution, however, is to respond not by restating his prior, established view that a basic restructuring of society, whether reformative or revolutionary, is possible and likely. Rather, Baldwin speaks to this moment by admitting to the fullest the possibility that hopes for justice-and his own artistic practice-have been empty, but also presenting the need for such hopes and such an art, and the counterposed possibility that they are true. Just Above My Head, then, finally works not as lament and memorial, nor even as artistic self-questioning, but as a presentation of choices. And this presentation is itself a fulfillment of Baldwin's role as 
prophetic artist, for the choice Baldwin presents is real and fundamental. The biblical prophets often presented such choices, but in the form of the community's obligation to accept or reject God's word. In Baldwin's secularized prophecy, there is no word of God, only alternative possibilities that humans must discern and decide between. Nor would it help Baldwin's case to privilege one over the other narratively. For, always, individuals and social groups must decide between ways of assessing reality based on their experiences, the ideas of their times, their driving moral and practical needs. What Baldwin has done as prophetic artist is to clarify the stakes-the costs and implications of each choice. His prophetic message is that in our own lives and time, we each must decide if rain will or can give way to renewing fire.

\section{Notes}

1 James Baldwin, Just Above My Head (New York, Delta, 2000), pp. 3, 522-3.

2 Ibid., p. 15.

32 Corinthians 5:7. Biblical quotations are from the Authorized (King James) Version.

4 Robert Reid-Pharr, Once You Go Black: Choice, Desire, and the Black American Intellectual (New York, New York University Press, 2007), p. 118.

5 Caryl Phillips, "Books: The Price of the Ticket," The Guardian (U.S. edition, online), 14 July 2007. TheGuardian.com (accessed 30 December 2014).

6 Baldwin told David Leeming during his last illness that "he did not 'believe' in God" (Leeming, James Baldwin: A Biography [New York, Knopf, 1994], p. 384). He more than once speaks of God as a human construct- "man's most intense creation," whose nature we "expand and transform" in an ongoing "act of creation" ("Preservation of Innocence," in Toni Morrison (ed.), James Baldwin, Collected Essays (New York, Library of America, 1998), p. 596; "White Racism or World Community?," ibid., p. 755). In an open letter to Bishop Desmond Tutu he calls himself "not a religious or, more precisely, a churchgoing man" ("The Fire This Time: Letter to the Bishop," in Randall Kenan (ed.), The Cross of Redemption: Uncollected Writings (New York, Pantheon, 2010), p. 215), but he never details the implied way in which he is "religious."

7 Clarence E. Hardy III, James Baldwin's God: Sex, Hope, and Crisis in Black Holiness Culture (Knoxville, University of Tennessee Press, 2003), pp. x, xiii. Hardy mentions Just Above My Head very briefly, see pp. 55-6, 63, 68. Hardy builds on a tradition including Stanley Macebuh's James Baldwin: A Critical Study (New York, Third Press, 1973), and Sondra A. O’Neale, "Fathers, Gods, and Religion: Perceptions of Christianity and Ethnic Faith in James Baldwin," in Fred L. Standley and Nancy V. Burt (eds.), Critical Essays on James Baldwin (Boston, G. K. Hall, 1988), pp. 125-43, whose influence Hardy notes (p. 122, n. 41). For alternative views, see, besides studies of particular texts, several interlinked essays by Michael F. Lynch, notably "Just Above My Head: James Baldwin's Quest for Belief," Literature and Theology, 11:3 (1997), pp. 284-98.

8 James Baldwin, Another Country (New York, Vintage International, 1993), pp. 22, 87-8; Tell Me How Long the Train's Been Gone (New York, Vintage International, 1998), pp. 98, 425.

9 Baldwin, Just Above My Head, pp. 435-52. 
10 E.g., Lynn Orilla Scott, James Baldwin's Later Fiction: Witness to the Journey (East Lansing, Michigan State University Press, 2002), p. 126.

11 See, e.g., Ziony Zevit, The Religions of Ancient Israel: A Synthesis of Parallactic Approaches (London, Continuum, 2001), Chap. 8; Renita J. Weems, Battered Love: Marriage, Sex, and Violence in the Hebrew Prophets (Minneapolis, Fortress, 1995).

12 See, e.g., David L. Petersen, "Introduction to the Prophetic Literature," in Leander E. Keck et al. (eds.), The New Interpreter's Bible, vol. 6 (Nashville, Abingdon, 1994), pp. 1-23, esp. pp. 8, 9, 20-1; and Petersen's The Prophetic Literature: An Introduction (Louisville, Westminster John Knox, 2002), p. 90. On apocalyptic literatures, see, e.g., Brian K. Blount, Can I Get a Witness?: Reading Revelation through African American Culture (Louisville, Westminster John Knox, 2005), esp. Chap. 2; John J. Collins, The Apocalyptic Imagination: An Introduction to Jewish Apocalyptic Literature (2nd edn.), (Grand Rapids, Eerdmans, 1998), Chap. 2 (on Daniel), esp. p. 114.

13 For discussion, see Cleophus J. LaRue, The Heart of Black Preaching (Louisville, Westminster John Knox, 2000), pp. 19, 114-15, and elsewhere.

14 James Baldwin, "Sonny's Blues," in Going to Meet the Man (New York, Vintage International, 1995), p. 140.

15 See Baldwin, Another Country (1962), pp. 286, 327, 330-2 for art, pp. 408-31 for reform; Tell Me How Long the Train's Been Gone (1968), pp. 476-82 for apocalyptic vision; If Beale Street Could Talk (1974) (New York, Delta, 2000), p. 163 for art, p. 166 for apocalyptic birth.

16 The best discussions of the novel are Scott, James Baldwin's Later Fiction, pp. 120-69; Reid-Pharr, Once You Go Black, pp. 96-118; and, on sexuality, Lee Edelman, Homographesis: Essays in Gay Literary and Cultural Theory (New York, Routledge, 1994), pp. 42-75. None focuses on prophetic or apocalyptic art or ideas. Most treatments of music in the novel, including Eleanor Traylor's early "I Hear Music in the Air: James Baldwin's Just Above My Head," First World 2:3 (1979), pp. 40-3, and D. Quentin Miller, "Using the Blues: James Baldwin and Music," in Douglas Field (ed.), A Historical Guide to James Baldwin (New York, Oxford University Press, 2009), pp. 102-9, emphasize blues and miss Gospel's coequal place in Baldwin's imagination; Peter Bruck, "Dungeon and Salvation: Biblical Rhetoric in James Baldwin's Just Above My Head," in Günter H. Lenz (ed.), History and Tradition in Afro-American Culture (Frankfurt, Campus, 1984), pp. 130-46, an exception, argues that Baldwin misunderstands the genre. Scott's chapter (above) also emphasizes Gospel. None mentions Baldwin's use of "Daniel," which Arthur sings in the scene discussed below, as an epigraph, or comments on its words.

17 Baldwin, Just Above My Head, pp. 108-11, 447-52.

18 Ibid., pp. 109-10 for communal experience, p. 21 for the artist as vessel.

19 On "commissioning" stories as a prophetic genre, see Petersen, The Prophetic Literature, pp. 20-1; Marvin A. Sweeney, The Prophetic Literature (Nashville, Abingdon, 2005), p. 36.

20 Baldwin, Just Above My Head, p. 52.

21 Ibid., p. 576.

22 Percy Bysshe Shelley, "A Defence of Poetry," in Donald H. Reiman and Sharon B. Powers (eds.), Shelley's Poetry and Prose (New York, Norton, 1977), p. 508.

23 Baldwin, Just Above My Head, pp. 501-12.

24 Ibid., p. 511. 
25 Ibid.

26 Ibid., pp. 511-12. I omit narration between song segments.

27 Daniel, 2:44-5.

28 For a contemporary account, see E. A. Randolph, The Life of John Jasper, Pastor of Sixth Mt. Zion Baptist Church, Richmond, Va. (etc.) (Richmond, R. T. Hill, 1884), pp. 142-57.

29 James Baldwin, The Fire Next Time (New York, Vintage International, 1993), p. 100; Martin Luther King Jr., "I Have a Dream" (speech text), in Eric J. Sundquist, King's Dream (New Haven, Yale University Press, 2009), p. 233.

30 Collins, The Apocalyptic Imagination, pp. 97-8; Gerhard von Rad, Old Testament Theology, vol. 2: The Theology of Israel's Prophetic Traditions, trans. D. M. G. Stalker (1965; reprinted, Louisville, Westminster John Knox, 2001), pp. 311-12.

31 In the epigraph, lineation varies and the last stanza reads "Daniel saw" rather than "Jesus is." (Both stanzas are traditional.) See Erskine Peters, Lyrics of the AfroAmerican Spirituals: A Documentary Collection (Westport, Greenwood, 1993), pp. 209-10.

32 Baldwin, Just Above My Head, pp. 512-13; see 2 Corinthians 5:1.

332 Corinthians, 5:2; 5:7.

34 Book Five (pp. 515-84) begins just after the Paris scene. Jimmy and Arthur become lovers within a few months (pp. 517-40) and are together "almost fourteen years" (p. 577). Present time is a further two years after Arthur's death (p. 5).

35 Baldwin, Just Above My Head, p. 419.

36 Student Nonviolent Coordinating Committee, "Statement of Purpose," in Staughton and Alice Lynd (eds.), Nonviolence in America: A Documentary History, Revised edition (Maryknoll, Orbis, 1995), p. 222.

37 Baldwin, Just Above My Head, pp. 25, 18.

38 Ibid., p. 18.

39 Ibid.

40 Ibid., pp. 25, 27.

41 Ibid., pp. 31-2, 37.

42 Ibid., pp. 452, 6.

43 Scott, James Baldwin's Later Fiction, p. 160.

44 Baldwin, Just Above My Head, p. 249.

45 Ibid., pp. 334-5. The comments are similar to Baldwin's own cited above, but Hall is assertive about his atheism: "[I]t was all a lie, from top to bottom: and, since we had built it, only we could dare it down" (p. 334).

46 Ibid., p. 562.

47 Ibid., pp. 136, 381, 430.

48 Ibid., pp. 27, 517.

49 Ibid., p. 6.

50 Ibid., p. 453.

51 Ibid., pp. 566-8.

52 Johnson Oatman Jr., "Lift Him Up" (1903), in The Cyber Hymnal, http://www. hymntime.com/tch/pdf/l/i/f/Lift\%20Him\%20Up\%20(Oatman).pdfs (accessed 26 June 2014).

53 Louis B. Gallien, Jr., "Crossing Over Jordan: Navigating the Music of Heavenly Bliss and Earthly Desire in the Lives and Careers of Three Twentieth-Century African 
American Holiness-Pentecostal 'Crossover' Artists,” in Amos Yong and Estrelda Y. Alexander (eds.), Afro-Pentecostalism: Black Pentecostal and Charismatic Christianity in History and Culture, (New York, New York University Press, 2011), p. 117 and elsewhere; pp. 119, 124-5 on sexuality.

54 Cooke's “A Change Is Gonna Come” (1964) and Gaye's album What's Going On? (1971) are examples.

55 Baldwin, Just Above, pp. 568, 578-9; “Feelin' Alright," on The Official Feelin' Alright Page, www.davemasonmusic.com/feelin-alright\#top (accessed 25 June 2014). Baldwin varies the lyrics and line breaks.

56 Baldwin, Just Above My Head, pp. 3, 523.

57 Ibid., p. 49.

58 Ibid., pp. 578-9. For contrasting views, see Warren J. Carson, "Manhood, Musicality, and Male Bonding in Just Above My Head," in D. Quentin Miller (ed.), ReViewing James Baldwin: Things Not Seen (Philadelphia, Temple University Press, 2000), p. 224; and Scott, James Baldwin's Later Fiction, p. 160.

59 Baldwin, Just Above My Head, p. 250.

60 Ibid., pp. 453, 523.

61 Ibid., pp. 575-6.

62 Ibid., p. 576.

63 Ibid., p. 577.

64 Ibid., p. 52.

65 On Smith, see Chris Albertson, Bessie (New Haven, Yale University Press, 2005), pp. 132-9. Reid-Pharr recalls childhood family acquaintances saying about Jackson, "You know. They say she was funny" (Once You Go Black, p. 106).

66 Baldwin, Just Above My Head, pp. 222-3.

67 Ibid., p. 267.

68 Ibid., p. 223.

692 Corinthians 5:7; paraphrased, Baldwin, Just Above, p. 15 (discussed earlier).

70 Baldwin, Just Above My Head, p. 18.

71 Reid-Pharr, Once You Go Black, pp. 118, 103, 104.

72 Baldwin, Just Above My Head, pp. 27, 32.

73 Ibid., p. 518.

74 Ibid., pp. 582-4.

75 Ibid., pp. 103-44.

76 Ibid., p. 583.

77 Ibid., pp. 583, 584. For the actual dream (by Baldwin's brother David) on which this one was based, see Leeming, James Baldwin, p. 345.

78 Baldwin, Just Above My Head, pp. 583-4.

79 For a nonfiction discussion, see Baldwin, "The Uses of the Blues," (1964) in Kenan (ed.), The Cross of Redemption, pp. 57-66.

80 Baldwin, Just Above My Head, p. 584.

81 Ibid.

822 Peter, 3:7, 10.

83 Daniel J. Harrington and Donald P. Senior, "Jude and 2 Peter," in 1 Peter, Jude and 2 Peter (Collegeville, MN, Michael Glazier-Liturgical Press, 2008), p. 287. Harrington cites antecedents in Isa. 66:15-16 and Mal. 4:1 (Ibid.). 
84 W. A. Criswell, "The World on Fire," 23 June 1974, in Criswell Sermon Library, www.wacriswell.com (accessed 10 February 2014). Criswell was pastor of First Baptist from 1944 to 1990, remaining in honorary posts until his death (2002).

85 Harrington, Jude and 2 Peter, pp. 235-7.

862 Peter, $2: 1 ; 3: 3 ; 3.4$

872 Peter, 3:6-7.

88 Baldwin, The Fire Next Time, pp. 105-6.

89 Harrington, Jude and 2 Peter, p. 287.

\section{Works Cited}

Albertson, Chris, Bessie, Revised edition, (New Haven, Yale University Press, 2005).

Baldwin, James, Another Country (New York, Vintage International, 1993).

The Fire Next Time (New York, Vintage International, 1993).

"Sonny's Blues," (1957) in Going to Meet the Man (New York, Vintage International, 1995), pp. 103-41.

"Preservation of Innocence," (1949) in Toni Morrison (ed.), Collected Essays (New York, Library of America, 1998), pp. 594-600.

- Tell Me How Long the Train's Been Gone (New York, Vintage International, 1998).

"White Racism or World Community?," (1968) in Collected Essays (New York, Library of America, 1998), pp. 749-56.

_If Beale Street Could Talk (New York, Delta, 2000).

- Just Above My Head (New York, Delta, 2000).

"The Fire This Time: Letter to the Bishop," (1985) in Randall Kenan (ed.), The Cross of Redemption: Uncollected Writings (New York, Pantheon, 2010), pp. 215-18.

"The Uses of the Blues," (1964) in Randall Kenan (ed.), The Cross of Redemption: Uncollected Writings (New York, Pantheon, 2010), pp. 57-66.

Blount, Brian K., Can I Get a Witness?: Reading Revelation through African American Culture (Louisville, Westminster John Knox, 2005).

Bruck, Peter, "Dungeon and Salvation: Biblical Rhetoric in James Baldwin's Just Above My Head," in Günter H. Lenz (ed.), History and Tradition in Afro-American Culture (Frankfurt, Campus, 1984), pp. 130-46.

Carson, Warren J., "Manhood, Musicality, and Male Bonding in Just Above My Head," in D. Quentin Miller (ed.), Re-Viewing James Baldwin: Things Not Seen (Philadelphia, Temple University Press, 2000), pp. 215-32.

Collins, John J., The Apocalyptic Imagination: An Introduction to Jewish Apocalyptic Literature (2nd edn.), (Grand Rapids, Eerdmans, 1998).

Criswell, W. A., "The World on Fire", 23 June 1974, in Criswell Sermon Library, www. wacriswell.com (accessed 10 February 2014).

Edelman, Lee, Homographesis: Essays in Gay Literary and Cultural Theory (New York, Routledge, 1994).

Gallien, Louis B., Jr., "Crossing Over Jordan: Navigating the Music of Heavenly Bliss and Earthly Desire in the Lives and Careers of Three Twentieth-Century African American Holiness-Pentecostal 'Crossover' Artists,” in Amos Yong and Estrelda Y. Alexander (eds.), Afro-Pentecostalism: Black Pentecostal and Charismatic Christianity in History and Culture (New York, New York University Press, 2011), pp. 117-38. 
Hardy, Clarence E., III, James Baldwin's God: Sex, Hope, and Crisis in Black Holiness Culture (Knoxville, University of Tennessee Press, 2003).

Harrington, Daniel J. and Senior, Donald P., "Jude and 2 Peter," in 1 Peter, Jude and 2 Peter (Collegeville, M.N., Michael Glazier-Liturgical Press, 2008), pp. 161-299.

King, Martin Luther, Jr., "I Have a Dream," [Speech text] in Eric J. Sundquist (ed.), King's Dream (New Haven, Yale University Press, 2009), pp. 229-34.

LaRue, Cleophus J., The Heart of Black Preaching (Louisville, Westminster John Knox, 2000).

Leeming, David, James Baldwin: A Biography (New York, Knopf, 1994).

Lynch, Michael F., "Just Above My Head: James Baldwin's Quest for Belief," Literature and Theology, 11:3 (1997), pp. 284-98.

Macebuh, Stanley, James Baldwin: A Critical Study (New York, Third Press, 1973).

Mason, Dave, "Feelin' Alright," On The Official Feelin' Alright Page, www. davemasonmusic.com/feelin-alright\#top (accessed 25 June 2014).

Miller, D. Quentin, "Using the Blues: James Baldwin and Music," in Douglas Field (ed.), A Historical Guide to James Baldwin (New York, Oxford University Press, 2009), pp. 83-109.

Oatman, Johnson, Jr., "Lift Him Up," (1903) in The Cyber Hymnal, http://www. hymntime.com/tch/pdf/l/i/f/Lift\%20Him\%20Up\%20(Oatman).pdfs (accessed 26 June 2014).

O’Neale, Sondra A., "Fathers, Gods, and Religion: Perceptions of Christianity and Ethnic Faith in James Baldwin," in Fred L. Standley and Nancy V. Burt (eds.), Critical Essays on James Baldwin (Boston, G. K. Hall, 1988), pp. 125-43.

Peters, Erskine, Lyrics of the Afro-American Spirituals: A Documentary Collection (Westport, Greenwood, 1993).

Petersen, David L., "Introduction to the Prophetic Literature," in Leander E. Keck et al. (eds.), The New Interpreter's Bible, vol. 6. (Nashville, Abingdon Press, 1994), pp. 1-23.

The Prophetic Literature: An Introduction (Louisville, Westminster John Knox, 2002).

Phillips, Caryl, "Books: The Price of the Ticket," The Guardian (U.S. edition, online), 14 July 2007. TheGuardian.com (accessed 30 December 2014).

Randolph, E. A., The Life of John Jasper, Pastor of Sixth Mt. Zion Baptist Church, Richmond, VA (etc.) (Richmond, R. T. Hill, 1884).

Reid-Pharr, Robert, Once You Go Black: Choice, Desire, and the Black American Intellectual (New York, New York University Press, 2007).

Scott, Lynn Orilla, James Baldwin's Later Fiction: Witness to the Journey (East Lansing, Michigan State University Press, 2002).

Shelley, Percy Bysshe, "A Defence of Poetry," in Donald H. Reiman and Sharon B. Powers (eds.), Shelley's Poetry and Prose (New York, Norton, 1977), pp. 480-508.

Student Nonviolent Coordinating Committee, "Statement of Purpose," (1960) in Staughton Lynd and Alice Lynd (eds.), Nonviolence in America: A Documentary History, Revised edition (Maryknoll, Orbis, 1995), p. 222.

Sweeney, Marvin A., The Prophetic Literature (Nashville, Abingdon Press, 2005).

Traylor, Eleanor, "I Hear Music in the Air: James Baldwin's Just Above My Head," First World, 2:3 (1979), pp. 40-3. 
Von Rad, Gerhard, Old Testament Theology. Vol. 2: The Theology of Israel's Prophetic Traditions. Translated by D. M. G. Stalker, 1965. Reprinted (Louisville, Westminster: John Knox, 2001).

Weems, Renita J., Battered Love: Marriage, Sex, and Violence in the Hebrew Prophets (Minneapolis, Fortress, 1995).

Zevit, Ziony, The Religions of Ancient Israel: A Synthesis of Parallactic Approaches (London, Continuum, 2001).

\section{Contributor's Biography}

Christopher Z. Hobson is a Professor of English at SUNY College at Old Westbury. He is author of Blake and Homosexuality and The Mount of Vision: African American Prophetic Tradition, 1800-1950 (Oxford, 2012). This article is drawn from a book in progress on Baldwin's use of religious imagery. 